\title{
Use of heparin in patients with severe COVID-19: What is the evidence?
}

\author{
Uso de heparina em pacientes com COVID-19 grave: Quais as evidências? \\ Uso de heparina en pacientes con COVID-19 grave: ¿Cuál es la evidencia?
}

Vitória Ribeiro Dantas Marinho ORCID: https://orcid.org/0000-0002-8514-1560 Potiguar University, Brazil Liga Norte Riograndense Contra o Câncer, Brazil

E-mail: vitoriardmarinho@hotmail.com

Camila Vilar de Oliveira Villarim ORCID: https://orcid.org/0000-0002-3173-7932 Potiguar University, Brazil Liga Norte Riograndense Contra o Câncer, Brazil E-mail: camilavillarim@gmail.com

Laura Cristina Costa e Silva

ORCID: https://orcid.org/0000-0002-2591-5085 Potiguar University, Brazil

Liga Norte Riograndense Contra o Câncer, Brazi E-mail: lauracristina_99@hotmail.com

André Luiz Costa e Silva

ORCID: https://orcid.org/0000-0001-7255-3833 University of Rio Grande do Norte, Brazil Liga Norte Riograndense Contra o Câncer, Brazil

E-mail: andreluizcostaesilva@hotmail.com

Irami Araújo-Neto

ORCID: https://orcid.org/0000-0003-3360-2991 Potiguar University, Brazil

Liga Norte Riograndense Contra o Câncer, Brazil

E-mail: irami.neto@uol.com.br

Diego Maia Diogenes Rabelo Caldas

ORCID: https://orcid.org/0000-0002-5163-8237

Potiguar University, Brazil

Liga Norte Riograndense Contra o Câncer, Brazil

E-mail: diego_dmaia@hotmail.com

Amália Cinthia Meneses Rêgo

ORCID: https://orcid.org/0000-0002-0575-3752

Potiguar University, Brazil

Faculdade de Saúde, Liga Contra o Câncer, Brazil

E-mail: regoamalia@gmail.com

Irami Araújo-Filho

ORCID: https://orcid.org/0000-0003-2471-7447

Potiguar University, Brazil

Universidade Federal do Rio Grande do Norte, Brazil

E-mail: irami.filho@uol.com.br

\begin{abstract}
The rapid spread of coronavirus disease (COVID-19) worldwide urges the need for studies on the illness and its management. The COVID-19 infection leads to hypercoagulation due to inflammatory cytokine release and D-dimer increase in critically ill patients, resulting in pulmonary thromboembolism (PE) and venous thromboembolism (VTE) evolving to sepsis and death. The study evaluated the currently existing evidence on heparin administration in patients with severe COVID-19. An integrative literature review was done by searching for scientific studies in the PubMed, Scopus, Embase, and Web of Science databases. The analyzed studies showed that heparin use in critically ill patients could efficiently prevent thrombotic events and reduce the exacerbated inflammatory process. However, further investigation on the effect on patients is still needed. The use of heparin in critically ill COVID-19 patients has been prescribed increasingly by doctors. But its use has not yet had its outcomes well established in the literature. Therefore, deeper investigations and new research development are needed to clarify potential beneficial effects.
\end{abstract}

Keywords: COVID-19; Heparin; SARS-CoV-2; Blood coagulation; Thrombosis; Anticoagulants. 


\begin{abstract}
Resumo
A rápida propagação da doença do coronavírus (COVID-19) em todo o mundo tornou urgente a necessidade de estudos sobre a doença e seu manejo. A doença promove um estado de hipercoagulação decorrente da liberação de citocinas inflamatórias, aumento de D-dímero, promovendo tromboembolismo pulmonar (TEP) e tromboembolismo venoso (TEV) observados nos pacientes graves infectados, podendo levar à sepse e morte. O estudo avaliou as evidências atuais existentes sobre a administração de heparina em pacientes com COVID-19. Realizou-se uma revisão integrativa da literatura através da busca de estudos científicos nas bases de dados PubMed, Scopus, Embase e Web of Science. De acordo com os estudos analisados, o uso de heparina nos pacientes graves se mostrou possivelmente capaz de evitar eventos trombóticos e reduzir o processo inflamatório exacerbado, no entanto ainda é necessária a investigação mais aprofundada sobre o efeito nos pacientes. Concluiuse que o uso de heparina nos pacientes COVID-19 graves tem sido cada vez mais prescrito pelos médicos, mas seu uso ainda não tem seus desfechos bem estabelecidos na literatura. Portanto, são necessárias investigações mais aprofundadas e desenvolvimento de novas pesquisas para melhor elucidação dos efeitos benéficos.
\end{abstract}

Palavras-chave: COVID-19; Heparina; SARS-CoV-2; Coagulação sanguínea; Trombose; Anticoagulantes.

\title{
Resumen
}

La rápida propagación del coronavirus (COVID-19) en todo el mundo ha hecho urgente la necesidad de estudios sobre la enfermedad y su manejo. La enfermedad promueve un estado de hipercoagulación resultante de la liberación de citocinas inflamatorias, un aumento del dímero D, que promueve el tromboembolismo pulmonar (TEP) y el tromboembolismo venoso (TEV) observado en pacientes críticamente infectados, que puede conducir a sepsis y a la muerte. El estudio evaluó la evidencia actual existente sobre la administración de la heparina en pacientes con COVID-19. Se realizó una revisión íntegra de la literatura mediante la búsqueda de estudios científicos en las bases de datos PubMed, Scopus, Embase y Web of Science. Según los estudios analizados, se ha demostrado que el uso de la heparina en pacientes críticamente enfermos posiblemente sea capaz de prevenir eventos trombóticos y reducir el proceso inflamatorio exacerbado, aunque se necesita más investigación sobre el efecto en los pacientes. Se concluyó que el uso de la heparina en pacientes críticos con COVID-19 ha sido prescrito cada vez más por los médicos, pero su uso aún no ha tenido resultados bien establecidos en la investigación. Por lo tanto, se necesitan investigaciones más profundas y el desarrollo de nuevos estudios para aclarar mejor los efectos beneficiosos. Palabras clave: COVID-19; Heparina; SARS-CoV-2; Coagulación sanguínea; Trombosis; Anticoagulante.

\section{Introduction}

In late 2019, in Wuhan, China, an acute respiratory disease caused by the SARS-CoV-2 virus, the coronavirus disease (COVID19), emerged. Due to its potent virulence, the severe acquired coronavirus respiratory syndrome spread rapidly in several countries, becoming a world pandemic declared by the World Health Organization in March 2020 (Marietta et al., 2020; Bocchese et al., 2020; Dantas et al., 2021; Marinho et al., 2021).

Most of the infected patients developed mild manifestations and a good prognosis. However, some had severe forms of the disease and died from multiple systemic complications (Marietta et al., 2020).

The most common symptoms are fever, dry cough, dyspnoea, fatigue, headache, gastrointestinal manifestations, dysgeusia, and anosmia. However, the disease affects the most diverse organ systems and can manifest varied clinical conditions (Góes et al., 2020).

More than a year after the COVID-19 outbreak, it was possible to observe the relationship between the mechanisms of disease severity causing an exacerbated immune response triggered by the host and the elevation of inflammatory biomarkers (Marietta et al., 2020).

According to Miesbach and Makris (2020), the infection by COVID-19 promotes a systemic inflammatory response that evolves to sepsis-induced coagulopathy (SIC) and death of the affected individuals. The authors highlighted the increase in angiotensin II and the release of inflammatory cytokines as causes of coagulopathy in up to $50 \%$ associated with poor prognosis.

Therefore, the prescription of prophylactic anticoagulation was recommended, with low molecular weight heparin (LMWH) early to prevent thrombotic events, organ failure (Miesbach, \& Makris, 2020; Riveros et al., 2020), and the inflammatory effects of the disease (Lindahl, \& Li, 2020).

However, Riveros et al. (2020) point out how the coronavirus pandemic demands urgency in the responses of the health system regarding the conduct of these patients. Uncertainties about management mean that doctors need to make decisions that are still under scientific investigation. 
Given the above, urges the need for further studies to optimize the patient follow-up (Boccia et al., 2020) and investigate the heparin effect in COVID-19 infected patients. Attributable to the hemostatic disorders caused by the expression of the hypercoagulable state (Riveros et al., 2020).

In this sense, the present review aimed to analyze and discuss the current evidence for the heparin administration in patients with COVID-19.

\section{Methodology}

Proceeded an integrative literature review in search of the current evidence on the use of heparin in patients with COVID-19. The research happened on February 11, 2021. The PubMed, Scopus, Embase, and Web of Science databases were used, by the keywords COVID-19, heparin, SARS-CoV-2, blood coagulation, thrombosis, and anticoagulants, in search of research published in Spanish, English, and Portuguese, in the last year. At the end of the data search, were found 54 features on the specific topic. A critical analysis of the available evidence was carried out, adopting the following steps for inclusion or not of the studies: selection by peers and blindly, with a third reviewer in case of divergences; exclusion in which the title or abstract was not consistent with the purpose of this review; exclusion of repeated jobs; full reading and detailed analysis of the selected studies. According to the sequence described above, excluded ten articles because they did not fill the required requirements. After the entire process, were decided 20 articles to compose the present review (Pereira et al., 2018).

\section{Results and Discussion}

The effectiveness of heparin in patients affected by SARS-CoV-2 is divergent. Current insights talk about the virus's ability to trigger an inflammatory cascade involving cytokines (Marietta et al., 2020; Boccia et al., 2020; Riveros et al., 2020) combined with a state of hypercoagulation (Marietta et al., 2020; Boccia et al., 2020; Lindahl, \& Li, 2020; Riveros et al., 2020; Schmoch et al., 2021), especially in critically ill patients admitted to the intensive care unit (ICU) (Riveros et al., 2020; Schmoch et al., 2021). Thus, it is necessary to have alternatives to control this situation.

According to Gómez-Mesa et al. (2021), are factors indicative of poor prognosis in patients hospitalized with severe COVID19: the presence of comorbidities, SIC score > 4, increased D-dimer, C-reactive protein, troponins, and other disseminated intravascular coagulation parameters. Including Boccia et al. (2020) and Guevara-Noriega et al. (2020) point to disseminated intravascular coagulation as present in the majority of deceased patients. Furthermore, Maldonado et al. (2020) add fibrin/fibrinogen degradation markers as a sign of worse evolution.

Therefore, Gómez-Mesa et al. (2021) added the importance of initial anticoagulation therapy with LMWH. Due to a mortality reduction of $48 \%$ in 7 days and $37 \%$ in 28 days. Besides that, an improvement on arterial oxygen pressure/ inspired oxygen fraction relation ( $\mathrm{PaO} 2 / \mathrm{FiO} 2)$. Due to the containment of the formation of microthrombi and associated pulmonary coagulopathy.

According to Miesbach and Makris (2020), the disseminated intravascular coagulation (DIC) associated with COVID-19 is precisely due to both the release of cytokines and the increase in D-dimer levels. These phenomena cause thromboembolic complications, diagnosed in up to 50\% of patients admitted to the ICU for more than two weeks (Ranucci et al., 2020).

Heparin is the most used anticoagulant medical practice to prevent thrombosis and extracorporeal treatments. Heparin is a biopolymer composed of trisulfated disaccharides. It functions through a double action: stopping thrombin production and inhibiting antithrombin protease III (AT-III). What leads to the interruption of thrombin activity, as explained by Seffer et al. (2020).

Seffer et al. (2020) and D'Souza et al. (2020) highlighted several other heparin pharmacological properties. For example, antiinflammatory, antiviral, antiangiogenesis, antineoplastic, and antimetastatic effects. Due to the interaction with mediators, like proteases, protease inhibitors, chemokines, cytokines, and growth factors. Thus, besides thrombosis prophylaxis, heparin is also possibly beneficial in patients with severe COVID-19 due to its anti-inflammatory properties. 
According to Stratton et al. (2020), to identify patients susceptible to the benefits of anticoagulant therapy, it is necessary to request platelet count, troponin, prothrombin time, fibrinogen, D-dimer and, creatinine clearance values. However, the author cites the need for further studies to prove this therapeutic decision and the intervals between exams.

Miesbach and Makris (2020) demonstrated the functionality of LMWH in SARS-CoV-2, which acts as hindering viral replication such as an anti-inflammatory, confirmed from the identification of lower interleukin 6 (IL-6) serum levels and higher lymphocytes in patients who used LMWH compared with patients who did not. However, changes in other inflammatory factors were not statistically significant. In addition to that, the authors also observed how the initially elevated levels of D-dimer and fibrinogen degradation products decreased significantly after treatment with LMWH, indicating an improvement in the hypercoagulable state in patients with ongoing severe COVID-19.

Regarding the incidence of Deep Venous Thrombosis (DVT) and Pulmonary Thromboembolism (PE) in infected individuals, although Miesbach and Makris (2020) suggest a similar incidence, Schulman (2020) describes a predominance of PE compared to DVT due to inflammatory reaction predominant in the lungs.

In a research carried out in China, Schulman (2020) evaluated 81 patients treated in the ICU examined through doppler ultrasonography of the veins of lower limbs associated with computed tomography of the chest. Of the 81 cases, 20 (25\%) developed DVT. In this group, the D-dimer value was significantly higher when compared to patients who did not have this complication.

In addition, in the work XPRESS (Xigris and Prophylactic Heparin Evaluation in Severe Sepsis), 1,994 septic patients were randomized for prophylaxis against venous thromboembolism (VTE) using heparin versus placebo. Was observed a similar incidence of VTE in patients who had had treatment with unfractionated heparin (UFH) (5.6\%), LMWH (5.9\%), or placebo (7.0\%) (Schulman, 2020).

Another research conducted by Schulman (2020), PROTECT (Prophylaxis for Thromboembolism in Critical Care Trial), randomized 3,764 critically ill patients to LMWH or UFH and, in general, the incidence of venous thromboembolism was similar. However, LMWH was associated with a lower risk of PE.

Based on the results obtained by Tang et al. (2020), Miesbach and Makris (2020) and Riveros et al. (2020), evaluated a sample of 449 patients (181 women and 268 men) with the severe form of COVID-19, with a mean age of $65.1 \pm 12.0$ years, in which more than $20 \%$ met the criteria for SIC. These patients were using LMWH, UFH, or none of the medications. At the end of the study, no statistically significant difference was observed regarding mortality between users or not of heparin, regardless of the form of presentation.

Tang et al. (2020) suggest favorable results on the use of heparin only in patients with high D-dimer or installed SIC. That was confirmed by Riveros et al. (2020), deducing that, in this group, 28-day mortality was $20 \%$ lower in patients treated with heparin. Based on these findings, they conclude how anticoagulant therapy may be associated with a better prognosis in patients with severe COVID19, patients with SIC, and elevated serum D-dimer levels.

Along with that, Riveros et al. (2020) aim that, in high-risk cases, with D-dimer $\geq 4$ times the upper limit of normal, the prophylactic dose of LMWH (40mg/enoxaparin- 12/12hrs) or sodium UFH $(12 \mathrm{U} / \mathrm{kg} / \mathrm{h})$ is indicated for the prevention of microthrombosis and an increase in the incidence of VTE.

An important observation evidenced by Barnes et al. (2020) is that many of these patients, besides the COVID-19 infection, already had risk factors for VTE. The concomitance of old age, comorbidities, pregnancy, congestive heart failure, or personal history of thromboembolism. In other words, most patients in intensive care would already have a previous indication to receive proph ylaxis for VTE, considering pre-existing guidelines. Compiling these considerations, Riveros et al. (2020) noted the scarcity of scientifically validated data on the effectiveness of full anticoagulation in patients with COVID-19.

On the other hand, a cohort study carried out by Helms et al. (2020) comparing the occurrence of thrombotic events in patients with COVID-19 treated with prophylactic or therapeutic heparin dose showed a higher number of clinically relevant thrombotic events 
in the preventive group when compared to the therapeutic group. This finding highlight that, in the context of SARS-CoV-2, greater attention is necessary to thromboprophylaxis, given that the thrombotic process starts at the initial inflammatory course, and the risk of thrombosis increases during its progression. This conclusion further confirms what was mentioned by other researchers: there is a lack of randomized clinical trials comparing anticoagulation targets in patients with COVID-19.

Iba et al. (2021) stated that the increase in inflammatory cytokines serum levels causes the SIC. That phenomenon leads to coagulation stimulated by a hyperactivation immune event. This process is similar to hemophagocytic syndrome, a rare immune disease. They declared the physiopathogenesis of this syndrome to cause an exaggerated activation of macrophages, making a generalized inflammation. The author points out that the use of heparin cases is still poorly studied, but it is promising, considering the results obtained by LMWH in Coronavirus-induced coagulopathy.

Added to this, Menezes-Rodrigues et al. (2020) defended the use of heparin in patients with COVID-19, claiming the benefit not only for combating coagulopathy, hypoxia, and organ failure but also for mitigating arrhythmias and sudden deaths resulted from the disease.

Lastly, Marietta et al. (2020) referred to the will of frontline doctors to adopt conducts and make decisions without concrete scientific evidence to reduce daily clinical complications, attending to the needs of their patients. However, a deep study of the pathophysiology of the disease and the development of high scientific research are essential to solidly assess the true efficacy and safety of the use of heparin in individuals affected by severe SARS-CoV-2.

\section{Conclusion}

In conclusion, the present study addressed the existing evidence for the therapeutic or prophylactic use of heparin in the severe form of SARS-CoV-2. The review showed that the benefits of using heparin in coronavirus-infected patients are controversial among the authors. The use of this class of medication by doctors has been increasing in their daily lives, attempting to prevent and treat thromboembolic events from the severe form of the disease. However, it is relevant to highlight the methodological biases observed in the analyzed studies, which interfere with the results, considering that many selected patients presented inaccurate outcomes due to associated comorbidities. Thus, further studies are still needed to assess the efficacy and safety of using anticoagulants in critically ill COVID-19 patients.

In order to increase evidence in this topic, further studies are needed, such as randomized clinical trials and systematic reviews with meta-analysis, for better assessment and conclusion of the effectiveness of using heparin to treat severe Covid-19 patients.

\section{References}

Barnes, G. D., Burnett, A., Allen, A., Blumenstein, M., Clark, N. P., Cuker, A., Dager, W. E., Deitelzweig, S. B., Ellsworth, S., Garcia, D., Kaatz, S., \& Minichiello, T. (2020). Thromboembolism and anticoagulant therapy during the COVID-19 pandemic: interim clinical guidance from the anticoagulation forum. Journal of thrombosis and thrombolysis, 50(1), 72-81. https://doi.org/10.1007/s11239-020-02138-z.

Bocchese, N. V., Dávila, N. G., Rodrigues, M. B. M., Araújo-Neto, I., Costa, M. O., et al. (2020). COVID-19 and Liver Injury: Hepatology Perspectives. J Clin Gastroenterol Treat. 74(6). 10.23937/2469-584X/1510074.

Boccia, M., Aronne, L., Celia, B., Mazzeo, G., Ceparano, M., D'Agnano, V., Parrella, R., Valente, T., Bianco, A., \& Perrotta, F. (2020). COVID-19 and coagulative axis: review of emerging aspects in a novel disease. Monaldi archives for chest disease $=$ Archivio Monaldi per le malattie del torace, $90(2), 10.4081 /$ monaldi.2020.

Dantas, T. C. de A., Gomes, A. C. A., Lima, I. P. C., Lucas, B. B., Aguiar, M. R. de., Cavalcanti, T. C. de H., Pinheiro, F. I., Rêgo, A. C. M., \& Araújo-Filho, I. (2021). Corticosteroid therapy in patients with severe COVID-19. Research, Society and Development, 10(1), e58910112114. https://doi.org/10.33448/rsd-v10i1.12114.

D’Souza, R., Malhamé, I., Teshler, L., Acharya, G., Hunt, B. J., \& McLintock, C. (2020). A critical review of the pathophysiology of thrombotic complications and clinical practice recommendations for thromboprophylaxis in pregnant patients with COVID-19. Acta Obstet Gynecol Scand. 99. 1110- 1120. https://doi.org/10.1111/aogs.13962.

Goés, A. B. M., Cardoso, B. B., Tavares, F. A. F., do Monte, R. R. L., Melo, R. C., et al. (2020). COVID-19 and Nervous System: Under Estimated Clinical and Prognostic Aspects. Int J Neurol Neurother. 100(7). doi.org/10.23937/2378-3001/1410100.

Gómez-Mesa, J. E., Galindo-Coral, S., Montes, M. C., \& Muñoz Martin, A. J. (2021). Thrombosis and Coagulopathy in COVID-19. Current problems in cardiology, 46(3), 100742. https://doi.org/10.1016/j.cpcardiol.2020.100742. 
Guevara-Noriega, K. A., Lucar-Lopez, G. A., Nuñez, G., Rivera-Aguasvivas, L., \& Chauhan, I. (2020). Coagulation Panel in Patients with SARS-CoV2 Infection (COVID-19). Annals of clinical and laboratory science, 50(3), 295-298.

Helms, J., Severac, F., Merdji, H., Schenck, M., Clere-Jehl, R., Baldacini, M., Ohana, M., Grunebaum, L., Castelain, V., Anglés-Cano, E., Sattler, L., \& Meziani, F. (2021). Higher anticoagulation targets and risk of thrombotic events in severe COVID-19 patients: bi-center cohort study. Ann Intensive Care. 11(1). https://doi.org/10.1186/s13613-021-00809-5

Iba, T., Warkentin, T. E., Thachil, J., Levi, M., \& Levy, J. H. (2021). Proposal of the Definition for COVID-19-Associated Coagulopathy. Journal Of Clinical Medicine. 10(2), 191. https://doi.org/10.3390/jcm10020191.

Lindahl, U., \& Li, J. P. (2020). Heparin - An old drug with multiple potential targets in Covid-19 therapy. Journal of thrombosis and haemostasis: JTH, 18(9), 24222424. https://doi.org/10.1111/jth.14898.

Maldonado, E., Tao, D., \& Mackey, K. (2020). Antithrombotic Therapies in COVID-19 Disease: a Systematic Review. J GEN INTERN MED 35, 2698-2706. https://doi.org/10.1007/s11606-020-05906-y.

Marietta, M., Coluccio, V., \& Luppi, M. (2020). COVID-19, coagulopathy and venous thromboembolism: more questions than answers. Internal and emergency medicine, 15(8), 1375-1387. https://doi.org/10.1007/s11739-020-02432-x.

Marinho, V. R. D., Abreu, C. A., Pereira, L. H. M., \& Lemos, T. E. V. (2021). Aplicação de zinco em pacientes com COVID-19: o que há de evidência?. Science \& Saúde: Atualizações sobre o COVID-19,1(18), 170-179. https://doi.org/10.47402/ed.ep.c20212518201.

Menezes-Rodrigues, F. S., Tavares, J. G. P., Oliveira, M. P., Carvalho, R. G., Errante, P. R., Taha, M. O., Fagundes, D. J., \& Caricati-Neto, A. (2020). Anticoagulant and antiarrhythmic effects of heparin in the treatment of COVID-19 patients. Journal of thrombosis and haemostasis: JTH, 18(8), $2073-2075$. https://doi.org/10.1111/jth.14902.

Miesbach, W., \& Makris, M. (2020). COVID-19: Coagulopathy, Risk of Thrombosis, and the Rationale for Anticoagulation. Clinical and applied thrombosis/hemostasis. official journal of the International Academy of Clinical and Applied Thrombosis/Hemostasis, 26. https://doi.org/10.1177/1076029620938149.

Pereira, A. S., Shitsuka, D. M., Parreira, F. J., \& Shitsuka, R. (2018). Metodologia Da Pesquisa Científica (1st ed.). Santa Maria: Universidade Federal de Santa Maria.

Ranucci, M., Sitzia, C., Baryshnikova, E., Di Dedda, U., Cardani, R., Martelli, F., \& Romanelli, M. C. (2020). Covid-19-Associated Coagulopathy: Biomarkers of Thrombin Generation and Fibrinolysis Leading the Outcome. Journal of Clinical Medicine, 9(11), 3487. https://doi.org/10.3390/jcm9113487.

Riveira-Caravaca, J. M., Nðñez-Gil, I. J., Vivas, D., Viana-Llamas, M. C., Uribarri, A., Becerra-Muñoz, V. M., Trabattoni, D., Rozas, I. F., Feltes, G., \& López-Pais, J. (2020). Clinical profile and prognosis in patients on oral anticoagulation before admission for COVID-19. European Journal Of Clinical Investigation, [S.L.], 51(1), 111. https://doi.org/10.1111/eci.13436.

Riveros, D., Maymó, D., Laviano, J., Fornillo, F. F., Fernández, J., Benzadon, R., Solimano, J., Cacchione, R., Riera, L., Duarte, P., Cazap, N., Gotta, D., García Altuve, J., Valentini, R., \& Dupont, J. (2020). Coagulopatía y COVID-19. Recomendaciones para una realidad cambiante [Coagulopathy and COVID-19. Recommendations for a changing reality]. Medicina, $80(5), 505-511$.

Seffer, M-T., Cottam, D., Fornic, L. G., \& Kielsteina, J. T. (2020). Heparin 2.0: A New Approach to the Infection Crisis. Karger Journals, 50(1), 28-34. https://doi.org/10.1159/000508647.

Schmoch, T., Brenner, T., Becker-Pennrich, A., Hinske, L. C., Weigand, M. A., Briegel, J., Möhnle, P., \& SepNet Study Group (2021). Therapie der sepsisinduzierten Koagulopathie: Ergebnisse einer deutschlandweiten Umfrage auf Intensivstationen [Treatment of sepsis-induced coagulopathy: Results of a Germany-wide survey in intensive care units]. Der Anaesthesist, 1-9. Advance online publication. https://doi.org/10.1007/s00101-021-00916-9.

Schulman, S. (2020). Coronavirus Disease 2019, Prothrombotic Factors, and Venous Thromboembolism. Semin Thromb Hemost. 46(7). 772-776. https://doi.org/10.1055/s-0040-1710337.

Stratton, C. W., Tang, Y., \& Lu, H. (2020). Pathogenesis-directed therapy of 2019 novel coronavirus disease. Journal Of Medical Virology. 93(3), 1320-1342. https://doi.org/10.1002/jmv.26610.

Tang, N., Bai, H., Chen, X., Gong, J., Li, D., \& Sun, Z. (2020). Anticoagulant treatment is associated with decreased mortality in severe coronavirus disease 2019 patients with coagulopathy. Journal of thrombosis and haemostasis: JTH, 18(5), 1094-1099. https://doi.org/10.1111/jth.14817. 